\title{
The effects of flexibility in employee skills, employee behaviors, and human resource practices on firm performance
}

\author{
Mousumi Bhattacharya \\ Fairfield University, mbhattac@fairfield.edu \\ Donald E. Gibson \\ Fairfield University, dgibson@mail.fairfield.edu \\ D. Harold Doty
}

Follow this and additional works at: https://digitalcommons.fairfield.edu/business-facultypubs Copyright 2005 Sage Publications.

This is the author's pre-print of an article subsequently published in the Journal of Management 31(4) 622-640 August 2005.

\section{Repository Citation}

Bhattacharya, Mousumi; Gibson, Donald E.; and Doty, D. Harold, "The effects of flexibility in employee skills, employee behaviors, and human resource practices on firm performance" (2005). Business Faculty Publications. 49.

https://digitalcommons.fairfield.edu/business-facultypubs/49

\section{Published Citation}

Bhattacharya, M., Gibson, D., Doty, D.H. (Aug. 2005). The effects of flexibility in employee skills, employee behaviors, and human resource practices on firm performance. Journal of Management 31(4) 622-640.

This item has been accepted for inclusion in DigitalCommons@Fairfield by an authorized administrator of DigitalCommons@Fairfield. It is brought to you by DigitalCommons@Fairfield with permission from the rightsholder(s) and is protected by copyright and/or related rights. You are free to use this item in any way that is permitted by the copyright and related rights legislation that applies to your use. For other uses, you need to obtain permission from the rights-holder(s) directly, unless additional rights are indicated by a Creative Commons license in the record and/or on the work itself. For more information, please contact digitalcommons@fairfield.edu. 
THE EFFECTS OF FLEXIBILITY IN EMPLOYEE SKILLS, EMPLOYEE

BEHAVIORS, AND HR PRACTICES ON FIRM PERFORMANCE

FORTHCOMING IN JOURNAL OF MANAGEMENT

MOUSUMI BHATTACHARYA

Charles F. Dolan School of Business

Fairfield University

Fairfield, CT 06824-5195

Phone: (203) 254-4000 ext. 2893

Fax: (203) 254-4105

E-mail: mbhattac@mail.fairfield.edu

\section{DONALD E. GIBSON}

Charles F. Dolan School of Business

Fairfield University

Fairfield, CT 06824-5195

Phone: (203) 254-4000 ext. 2841

Fax: (203) 254-4105

E-mail: dgibson@mail.fairfield.edu

\section{HAROLD DOTY}

School of Business \& Economic Development

The University of Southern Mississippi

2701 Hardy Street

Hattiesburg, MS 39406

Phone: (601) 266-4660

E-mail: Harold.Doty@usm.edu

The first author acknowledges the support of Fairfield University, Charles F. Dolan School of Business Research Committee. 


\title{
THE EFFECTS OF FLEXIBILITY IN EMPLOYEE SKILLS, EMPLOYEE BEHAVIORS, AND HR PRACTICES ON FIRM PERFORMANCE
}

\author{
ABSTRACT \\ Current strategic human resource management theory suggests that HR flexibility is a \\ dynamic capability facilitating a firm's rapid response to changing economic environments, thus \\ creating value. However, the components of HR flexibility and their potential relationship to \\ firm performance have not been empirically examined. We hypothesize that flexibility of \\ employee skills, employee behaviors, and HR practices represent critical sub-dimensions of HR \\ flexibility and are related to superior firm performance. Results based on perceptual measures of \\ HR flexibility and accounting measures of firm performance support this prediction. While skill, \\ behavior, and HR practice flexibility are significantly associated with an index of firm financial \\ performance, we find that only skill flexibility contributes to cost efficiency.
}




\section{The Effects of Flexibility in Employee Skills, Employee Behaviors, and HR Practices on Firm Performance}

Flexibility is the ability of a firm to respond to various demands from its dynamic competitive environment (Sanchez, 1995). Scholars have suggested that human resource (HR) flexibility in particular is a valuable firm capability (MacDuffie, 1995; Milliman, Von Glinow, \& Nathan, 1991; Wright \& Boswell, 2002; Wright \& Snell, 1998), and this is especially true in the current business environment, characterized as it is by rapid economic changes and shifting strategic demands (Hitt, Keats, \& DeMarie, 1998). Although researchers have shown that flexibility in other functional areas of the firm, such as operational flexibility, product customization, and resource flexibility is related to increased firm performance (Garud \& Kotha, 1994; MacDuffie, 1995; Parthasarthy \& Sethi, 1993; Rangan, 1998; Thomke, 1998), HR flexibility and its possible contribution to firm performance and competitive advantage has not been examined empirically.

We assert that HR flexibility is a dynamic capability of the firm (Eisenhardt \& Martin, 2000; Teece, Pisano, \& Shuen, 1997; Zollo \& Winter, 2002) in the sense that it is focused on adapting employee attributes—-such as knowledge, skills, and behaviors- to changing environmental conditions (Wright, Dunford, \& Snell, 2001; Wright \& Snell, 1998). Wright and Snell (1998) propose that HR flexibility is comprised of three sub-dimensions: employee skill flexibility, employee behavioral flexibility, and HR practice flexibility. The current study contributes to and extends this line of reasoning by examining (1) the degree to which these proposed dimensions are distinct; and (2) the degree to which they are linked with firm performance.

Research on the potential benefit of flexible employee skills and behaviors has employed different levels of analysis and used multiple, and often inconsistent, explanatory concepts. At 
the individual level, scholars have investigated employee adaptability (Lepine, Colquitt, \& Erez, 2000; Pulakos, Arad, Donovan, \& Plamondon, 2000), but have generally not linked this dimension to firm-level outcomes. Human capital dimensions such as education and experience (Hitt, Bierman, Shimizu, \& Kochhar, 2001) and employee behaviors such as mimetic adoption (Greve, 1998) and employee resistance (Larsson \& Finkelstein, 1999) have been related to the firm-level outcomes, but studies tend to treat skills and behaviors separately rather than as potentially integrated. At the organization level, the learning literature has emphasized that firms need to create, acquire, and transfer knowledge, thus modifying behavior (Garvin, 1993; Hedberg, 1981; Lei, Hitt, \& Bettis, 1996), but has not investigated how employee skills and behaviors are associated with learning. The strategic human resource management (SHRM) literature has examined high-performance HR practices and the degree to which they contribute to firm performance (e.g., Delery \& Doty, 1996; Huselid, 1995). However, these studies do not specifically address whether these practices are flexible or examine how employee skills and behaviors contribute to or interact with high-performance HR practices.

In this article we contribute to the HR management literature in three ways. First, we integrate individual- and organization-level approaches, asserting that HR flexibility is a firmlevel capability arising out of individual skills and behaviors and implemented through HR practices. Second, we develop the first exploratory survey aimed specifically at distinguishing and measuring the construct of HR flexibility and its components. Third, we examine how the components of HR flexibility_ — as distinct from high performance work practices — are related to financial measures of firm performance, a relationship that has been proposed but not empirically tested. By exploring the nuances of HR flexibility we hope to enhance researchers' and managers' understanding of the components and implications of this construct. 


\section{THEORY AND HYPOTHESES}

\section{Dimensions of HR Flexibility}

Wright and Snell (1998) theorized that HR flexibility is an internal trait or characteristic of the firm that can be addressed through three conceptual components: employee skills, employee behavior, and HR practices. Flexibility of employee skills is the "number of potential alternative uses to which employee skills can be applied" (Wright \& Snell, 1998: 764), and "how individuals with different skills can be redeployed quickly” (Wright \& Snell, 1998: 765). Employee behavior flexibility represents adaptable as opposed to routine behaviors; it is the extent to which employees possess a broad repertoire of behavioral scripts that can be adapted to situation-specific demands. Flexibility of HR practices is the extent to which the firm's HR practices can be adapted and applied across a variety of situations, or across various sites or units of the firm, and the speed with which these adaptations and applications can be made.

\section{HR Flexibility and Firm Financial Performance}

Strategic HRM researchers have assessed firm profitability, productivity and cost efficiency in exploring the relationship between HRM and firm performance (Becker \& Gerhart, 1996; Becker \& Huselid, 1998; Huselid, 1995). These researchers argue that HR can affect firm profitability through improved labor productivity, through greater cost efficiency, and by adding value through human assets. For example, Becker and Huselid (1998) suggest that the HRM-firm performance relationship is largely driven by more efficient management of the firm's HR, thus contributing to lower operating costs. However, they also suggest that effective HR systems lead to acquiring, motivating, and developing intellectual assets that can be a source of competitive advantage, highlighting HRM's value-adding role (see also Becker \& Gerhart, 1996). Since we investigate whether HR flexibility is related to firm competitive advantage, we define performance at the aggregate firm level. In order to capture the firm-level effects of HR 
flexibility, we combine the effects of productivity, profitability and cost efficiency in our operational definition of firm financial performance.

By including cost efficiency in our performance measure, we are asserting that HR flexibility will have a positive relationship with cost efficiency due to the cumulative direct and indirect synergistic effects between the HR dimensions of skill, behavior, and HR practices. We recognize that some scholars have argued that flexibility, which entails a wider range of resources and less process routine, may entail a trade-off with efficiency and actually increase costs (Lewis, 2000; Thompson, 1967; Weick, 1979). To address the assertion that the HR flexibility-efficiency relationship may differ from the HR flexibility-financial performance relationship, we consider cost efficiency 1) as part of an index of firm performance measures, and 2) as a separate measure, allowing us to specifically examine the proposed relationship.

Employee skill flexibility and firm financial performance. Skill flexibility can be generated in two different ways. First, firms may have employees who possess a set of broadbased skills and are capable of utilizing them under different demand conditions. Broad-based skills are valuable because they generate output streams for existing requirements and are also capable of producing output for possible alternative requirements. Skills possessed by employees but not currently used may open up new opportunities of business for the firm, and indeed, may influence strategic choices (Lengnick-Hall \& Lengnick-Hall, 1988). Second, firms may employ a wide variety of "specialist" employees who provide flexibility by allowing the firm to reconfigure skill profiles to meet changing needs. With this flexibility, when the need arises, the firm may reorganize its employees (e.g., through project teams) in order to achieve the desired skill profile to fit with the changed demand (Neuman \& Wright, 1999). Thus, a wide range of employee skills contributes to flexibility. This wide range can be gained by having a smaller 
number of employees with broad-based skills, or a larger number of employees with more narrow, specialist skills.

Broad-based skills are even more complex and difficult to imitate because these refer to a wider array of skills generated by a larger number of diverse experiences. At the organizational level, firms develop their own combination of skills with the variety of HR applications they implement over a number of years. A firm may develop skill flexibility through processes such as job-rotation, cross-functional teams, and project-based work arrangements, all of which generate broad skill configurations specific to the firm that are not easily replicable. This suggests that the higher the level of a firm's skill flexibility, the more likely they are to exhibit higher performance. We hypothesize that,

Hypothesis 1: Employee skill flexibility is positively related to firm financial performance.

Employee behavior flexibility and firm financial performance. Behavior flexibility is the capacity of people to adapt to changing situations, or to exhibit appropriate behavioral repertoires under different situations (Lepine et al., 2000; Pulakos et al., 2000). It can be distinguished from skill flexibility in the sense that employees may be skilled but lack the behavioral motivation to change or they may be highly motivated but lack the necessary skills or knowledge to make change decisions (MacDuffie, 1995). Recent research suggests that individuals differ in their capacity to adapt to change and that personality inventories may provide one method of determining an individual's level of adaptability (Lepine et al., 2000). Thus, firms can enhance their behavioral flexibility by intentionally recruiting individuals who exhibit higher levels of adaptability. Behavior flexibility also involves a greater tolerance for non-routine behavior on the part of the firm, which can only be achieved by fostering an appropriate culture (March, 1991). Therefore, behavior flexibility develops over a period of time. 
Behavior flexibility creates value in two ways. First, an individual's ability to address different situations creates value because the organization is spared the costs of non-adjustments to changed situations. Adaptable individuals adjust to the complexities and novelties of changed situations (Lepine et al., 2000); therefore losses associated with lack of change are minimized. Second, at the organizational level, behavior flexibility is valuable because it enables the firm to deal with a variety of situations and facilitates change implementation. Having employees with enhanced learning capabilities means that the organization does not need to hire new people with new attributes to address environmental changes.

There is some evidence that behavioral flexibility at the organizational level contributes to firm performance. Kotter and Heskett (1992) found, in a study of corporate culture and performance, that cultures that emphasized adaptation to changing environmental forces were more likely to be high performing. Garvin (1993) contended that organizations that are superior at learning, defined as "creating, acquiring and transferring knowledge, and...modifying its behavior to reflect new knowledge and insights," can enhance performance (see also Baker \& Sinkula, 1999; Hunt \& Morgan, 1996), and recent empirical study finds some support for the association between the learning organization concept and firms' financial performance (Ellinger, Ellinger, Yang, \& Howton, 2002).

Based on this theory and research, we propose that:

Hypothesis 2: Employee behavior flexibility is positively related to firm financial performance.

HR practice flexibility and firm financial performance. HR practice flexibility creates value in several ways. First, the firm is more readily able to adapt its HR practices to changed situations. For example, employee compensation plans based on specific job descriptions may become institutionalized and difficult to change in the face of likely employee resistance. 
However, a variable compensation plan tied to profit measures (rather than jobs) adjusts more rapidly to increased or decreased profits (Milkovich \& Newman, 1999).

Second, flexibility of HR practices may induce flexible employee behaviors. In the prior example of variable compensation plans, employees may adapt more easily to changed business demands because their compensation is determined by how successful the firm can be in the changed scenario.

Third, HR practice flexibility allows the firm to offer similar HR practices across different units—achieving strategic consistency—while adapting parameters to meet local concerns. This facilitates reallocation and reconfiguration of employee skills. For example, it may be difficult to rotate employees if there are differences in benefits across units. At the same time not every benefit may be suitable in the same way for all units. If the benefits parameters are flexible (e.g., cafeteria or flexible benefits plan, $401 \mathrm{~K}$ plans with a wide choice of investment instruments), then it may be easier to relocate people. Similarly, an HR practice of appraising employees through behavioral observation scales may be more difficult to apply across the organization due to non-uniformity of behavioral expectations, compared with a practice such as Management by Objectives (Wright \& Snell, 1998).

We argue that firms that develop HR practice flexibility create a capability that is difficult to imitate and nonsubstitutable and will be able to respond more dynamically to environmental change. These characteristics are related to competitive advantage and thus, firm performance.

Hypothesis 3: HR practice flexibility is positively related to firm financial performance. Flexibility and Cost Efficiency. Although cost efficiency is a part of firm financial performance, it merits a separate analysis in relation to flexibility, as noted above. A debate exists in the literature as to whether flexibility is positively or negatively related to cost 
efficiency (Adler, Goldoftas, \& Levine, 1999; Dean \& Snell, 1996). Some researchers argue that flexibility is not compatible with low cost strategies because resources and processes that generate flexibility and increase variety may also entail higher costs (Lewis, 2000; Parthasarathy \& Sethi, 1993; Weick, 1979). Others contend that flexibility and efficiency are not necessarily two opposite ends of one continuum (Corbett \& Van Wassenhove, 1993; Gibson \& Birkinshaw, 2004), because high flexibility reduces the cost of obsolescence and, by helping firms to react to change, may reduce the costs of delayed change and missed opportunities.

We propose that increased HR flexibility will be positively associated with cost efficiency. We offer two justifications for our assertion. First, employee skill, behavior, and HR practice flexibility reside in the people who run, control, and manage the firm's other resources. Thus, these flexibilities may not only generate value by themselves, but may also facilitate synergies with other resources, creating strategic opportunities. For example, when a firm is able to use its skill flexibility to quickly respond to changed demand for products and services, it may also foster greater creativity, innovation, and first mover advantages.

A second reason that HR flexibility is associated with cost efficiency is that the opportunity cost of not being able to adapt through people is high. One reaction by firms facing a changing competitive environment is to downsize their workforce, sometimes dramatically, because they have more employees than they can maintain or because they need to hire new skills. However, research indicates that this tactic has many possible negative effects, including decreased morale in remaining employees (Brockner, Grover, Reed, DeWitt, \& O’Mally, 1987), an inability by the firm to achieve long-term returns (Cascio, Young, \& Morris, 1997), and lower overall firm performance (De Meuse, Vanderheiden, \& Bergmann, 1994). A firm that has developed skill, behavior, and HR practice flexibility, conversely, may be able to adapt to environmental crises with its existing human resource base. Overall, we assert that firms that 
exhibit increased employee skill, employee behavior and HR practice flexibility are able to avoid the opportunity costs of layoffs and turnover, and therefore are more cost efficient.

Hypothesis 4a: Skill flexibility is positively related to cost efficiency.

Hypothesis 4b: Behavior flexibility is positively related to cost efficiency.

Hypothesis 4c: HR practice flexibility is positively related to cost efficiency.

\section{METHOD}

\section{Sample and Survey}

The firms included in this study were chosen from the Industrial Machinery and Equipment industry (SIC 35) and the Food and Grocery Stores industry (SIC 54). We chose these industries to get substantial variation in business conditions. The Industrial Machinery and Equipment industry faces high uncertainty of demand and sales. For example, for US machine tool cutting types, market growth was $22.3 \%$ in $1995,8.9 \%$ in $1996,2.3 \%$ in $1997,14.3 \%$ in 1998 and $-16.5 \%$ in 1999 (Datamonitor, 2000). For US machine tool accessories, the market growth was $9.2 \%$ in $1995,4.0 \%$ in $1996,-0.6 \%$ in $1997,1.4 \%$ in 1998 , and $3.2 \%$ in 1999 (Datamonitor, 2000). In contrast, the Food and Grocery Stores industry is relatively stable. The market growth rate has been around 1\% from 1995 to 1999 (Datamonitor, 2000).

In these two industries, 629 firms met our inclusion criteria: a) to be publicly traded firms in the US, and b) to have more than fifty employees, in order to increase the likelihood that participating organizations had developed more formalized HR systems (see Huselid, 1995). The senior executive (CEO or President) of each firm and the highest-ranking HR executive (usually a vice president or director), identified from the Directory of Corporate Affiliations (2000) were sent a letter informing them of the study in April, 2000. A week later a cover letter and a survey were sent to them by mail. Since we wanted to measure flexibility as perceived at the firm level, respondents were chosen at the top-level only and were directed to address their responses to 
"employees whose jobs are most central to the production and distribution of your core products/services." After three weeks, a reminder letter and a copy of the original survey were mailed to those who had not yet responded.

A total of 123 usable questionnaires were returned from individual firms, resulting in a response rate of $20 \%$. Although this response rate is modest, previous studies have exhibited similar response rates for surveys from top level respondents (e.g., Huselid, 1995; Paxson, Dillman \& Tarnai, 1995). The respondents include 97 HR executives and 26 CEOs, each representing a different firm. The average tenure of the HR executives is 6.1 years, while that of the CEOs is 2.75 years. Sixty-five percent of the HR executives report directly to the CEO, while thirty-five percent report to lower-ranking executives. The median number of full time employees in the sample is 1,300 (mean $=7,827)$. Due to discontinuation of operations in the three years following the survey, our final sample size is 117. A means test between responding and non-responding firms on characteristics including size, debt-equity, capital intensity, R\&D intensity, sales growth, and the firm performance measures did not indicate any significant difference.

\section{HR Flexibility Measures}

Data from the survey were used for measuring skill, behavior, and HR practice flexibility. The multi-item 7-point Likert-type scale for each construct was developed in three stages. First, a preliminary set of items was collected from an extensive literature review and discussions with managers, business faculty and senior doctoral students. Second, a panel of HR practitioners and scholars analyzed these items. Modifications were made at this stage to address their suggestions. Third, a web-based pre-test of the scales was undertaken. Members of the HR and Business, Policy, and Strategy divisions of the Academy of Management (both academicians and practitioners) were invited to respond to the questionnaire items based on their organizations. 
Pretest participants were also encouraged to provide qualitative comments on the items. Twentyeight responses to the pre-test were received, eleven of which were practitioners. The comments received at this stage were incorporated and the face validity of the items was assessed based on these responses. The survey questionnaire had fifty items for the three dimensions of HR flexibility, out of which twenty-two were retained for final analysis (based on factor loadings, see Table 1).

\section{Firm Financial Performance Measures}

We measured firm financial performance based on accounting data extracted from Standard \& Poor's COMPUSTAT database. We selected two measures of overall productivity, one profitability ratio, and one overall cost efficiency ratio. Operating profit per employee is operating income divided by total employees, measured in thousands of dollars. Sales per employee is net sales divided by total employees, measured in thousands of dollars. Return on sales is the ratio of income before extraordinary items and taxes over net sales. Cost of sales over sales is the ratio of cost of goods sold over net sales. Although these are distinct accounting measures, they represent components of firm performance that are likely to be related. Therefore, for parsimony, an index of these four, representing overall aggregate firm financial performance, was used as our primary outcome measure.

Flexibility of human resources, although measured at a particular point of time in this study, is generated through processes and practices over a considerable period (Wright et al., 2001) and is really a proxy for equilibrium levels that would have been observed over several prior years. This necessitated that the dependent measures should also reflect performance levels over a longer period of time so as not to be affected by short-term fluctuations. Therefore, annual performance data were averaged over three financial years (2000-2002) to eliminate random 
fluctuations and anomalies in the data and to better approximate long-term firm performance (Shen \& Cannella, 2002).

\section{Control Variables}

In testing the hypotheses we used several control variables to account for the influence of possible industry- and firm-level factors. Industry is a single, dummy-coded variable. Size is the natural logarithm of total employees, as reported in the survey. Percentage of unionization is also derived from the survey data. From COMPUSTAT data we used three ratio measures as control variables. Debt-equity is the outstanding debt over net equity. Capital intensity is property, plant and equipment over total assets. $R \& D$ intensity is research and development expenses over net assets.

In addition, the field of strategic HRM has shown that certain "high performance" HR practices - including selectivity in recruitment, extensive training, formal performance appraisal, and pay for performance_-are associated with greater firm performance (Delery \& Doty, 1996; Huselid, 1995). Researchers argue that these HR practices contribute to firm performance by generating valuable and unique human capital, and specifically suggest that high performance practices can improve the skills, abilities, and motivation of current and potential employees (see Huselid, 1995: 635), aspects that we have argued are critical to HR flexibility. To ensure that the effects we are measuring are specifically the result of flexibility rather than related to high performance practices, we control for several of these practices in our regression analyses. We use an index of four practices (selectivity in recruitment, training, variable compensation, and performance appraisal), drawn from scales separate from those factor analyzed in Table 1 (see Appendix). 


\section{RESULTS}

We used exploratory factor analysis with one-, two- and three-factor solutions to test for the discriminant validity of skill, behavior, and HR practice flexibility as distinct constructs. A three-factor structure conforming to a priori items for skill, behavior, and HR practice flexibility was the one best supported (Table 1). Skill flexibility ( 7 items), behavior flexibility ( 8 items), and HR practice flexibility ( 7 items) loaded on three distinct factors (Table 1) and no major cross loadings were indicated. The three factors explained about 11\% (skill flexibility), 14\% (behavior flexibility), and 16\% (HR practice flexibility) of total variance. The reliability estimates (Cronbach's alpha) of skill, behavior, and HR practice flexibility scales are $.89, .92$, and .90 respectively (Table 2).

Insert Table 1 about here

Table 2 shows descriptive statistics and correlations among variables. As expected, the three flexibility measures are moderately correlated: .59 between skill and behavior flexibility; .50 between behavior and HR practice flexibility; and .35 between skill and HR practice flexibility. The firm financial performance index is positively correlated with all three dimensions of HR flexibility, and cost of sales over sales is negatively correlated with all of them, albeit weakly for HR practice flexibility. Correlations of the three HR flexibility dimensions with individual components making up the firm financial performance index (i.e., return on sales, operating profit per employee, sales per employee) are not substantially different from the index results.

Insert Table 2 about here 
To test our hypotheses we applied hierarchical regression analysis, entering the control variables first, followed by the high performance HR practice index, and then by skill, behavior and HR practice flexibility. We checked the VIFs (variance inflations factors) for a test of multicollinearity among the three HR flexibility dimensions (Myers, 1990; Neter, Wasserman, \& Kutner, 1990). All VIF factors were within acceptable limits, the maximum being 1.72.

Among the control variables, unionization shows a positive relationship with the firm financial performance index. While studies have found both positive and negative effects of unionization on productivity, at least one review asserts that "most studies" indicate that union workers are more productive than nonunion workers (Noe, Hollenbeck, Gerhart, \& Wright, 1994: 704). This productivity does not always translate into increases in profitability, however (see Abowd, 1989; Hirsch, 1991). It is likely that our findings reflect those of Addison and Hirsch (1989), who show that positive union productivity effects can be more pronounced in some industries. The high performance HR practices index also shows a positive relationship with firm financial performance, supporting the linkage between these practices and firm performance (Delery \& Doty, 1996; Huselid, 1995).

Hypothesis 1, that skill flexibility will be related to firm performance, is supported. The results in Table 3 show that skill flexibility is significantly related to the firm financial performance index $(b=.30, p<.001)$ after controlling for industry, size, unionization level, debt-equity ratio, capital intensity, R\&D intensity, and high performance HR practices. Skill flexibility explains $3 \%$ incremental variance in the firm performance index. The unstandardized coefficient for skill flexibility is $2,347.52$, with a standard error of 738.01. Dividing firm performance into its separate components - return on sales, operating profit per employee and sales per employee - revealed significant and positive relationships across all three $(b=.27, .26$, and .29 respectively, all $p<.01$ ). 
Insert Table 3 about here

Hypothesis 2 predicts that behavior flexibility is positively related with firm financial performance. We found support for this hypothesis. As reported in Table 3, the standardized coefficient estimate of behavior flexibility is $.21(p<.01)$. The unstandardized coefficient is $1,725.28$ with a standard error of 756.67 . Behavior flexibility explains $1 \%$ incremental variance in the firm performance index after entering our control variables and is significant for the three components of the index — return on sales, operating profit per employee, and sales per employee $(b=.19, .19$, and .14 respectively, all $p<.05)$.

Hypothesis 3 is also supported. Results indicate a positive relationship between HR practice flexibility and firm financial performance index (see Table 3). HR practice flexibility explains $2 \%$ incremental variance for firm performance index after the organizational control variables and high performance HR practices are entered. The standardized coefficient estimate is .23 $(p<.01)$ and the unstandardized coefficient is $1,919.31$ with a standard error of 899.26. Among the components of firm performance, HR practice flexibility is significantly related to return on sales, operating profit per employee, and sales per employee $(b=.12, .17, p<.05$ and $.20, p<.01$, respectively).

Hypotheses $4 \mathrm{a}, 4 \mathrm{~b}$, and $4 \mathrm{c}$ postulate that skill, behavior, and HR practice flexibility will be positively related with cost efficiency, which implies that greater flexibility is associated with lower costs. While all three dimensions are negatively related to costs, we find significant support for these hypotheses only in relation to skill flexibility (see Table 3). The standardized coefficient estimate of skill flexibility is negative and significant $(b=-.18, p<.05)$ and incremental variance is $2 \%$. The unstandardized coefficient is -1.94 with a standard error of 1.51 . Overall skill, behavior and HR practice flexibility together explain $8 \%$ incremental variance 
(over control variables) in the firm financial performance index and $4 \%$ incremental variation for cost efficiency.

\section{DISCUSSION AND CONCLUSION}

This study explores whether employee skill, employee behavior, and HR practice flexibility are associated with greater firm financial performance. Extending the theoretical arguments of previous scholars (Milliman et al., 1991; Wright \& Snell, 1998), we discuss HR flexibility as a potential dynamic capability of firms, providing a theoretical link between the dynamic capability and strategic HRM literatures. Scholars have discussed HR flexibility both as an overall capability of the firm (Lengnick-Hall \& Lengnick-Hall, 1988; Milliman et al., 1991) and one generated by specific dimensions (Wright \& Snell, 1998). This study develops measures showing that flexibility of the HR system can be assessed in terms of at least three dimensions: skill, behavior, and HR practice flexibility. Our exploratory factor analysis of the questionnaire items presented in Table 1 indicates that these dimensions are distinct but interrelated constructs that show reasonable discriminant validity.

Testing our hypotheses on the individual components of the firm financial performance index, we found that all three measures of HR flexibility are positively associated with return on sales, operating profit per employee, and sales per employee. For example, a one standard deviation increase in skill flexibility (.81), behavior flexibility (.90) and HR practice flexibility (.79) would increase return on sales by $1.3 \%, 0.64 \%$, and $0.15 \%$ respectively. Similarly, the effect on the productivity measure of operating profit per employee for a one standard deviation change in skill flexibility is $\$ 410$, in behavior flexibility, \$298, and HR practice flexibility, \$267. For sales per employee, the effects are \$1,808 in skill flexibility, \$904 in behavior flexibility, and $\$ 1,292$ in HR practice flexibility. These effects, although relatively modest (about $2-3 \%$ of the 
industry average), are noteworthy because they are over and above those of high performance HR practices.

We also investigated the relationship between HR flexibility and cost efficiency. While we found that skill flexibility was significantly related to cost efficiency, no significant effects for behavior and HR practice flexibility were found. Reflecting on this finding, we suggest that skill flexibility exhibits a larger role in reducing costs because greater skill variety and its application lower the requirement for actual buffers against uncertainty. Skill flexibility is more tangible in the sense that output from skill applications are often visible and can be seen in the short term. If a change in work requirement can be met from existing employees, the cost savings are immediate and apparent. Efficiencies derived from behavior are less visible and likely to have longer-term effects. For example, it may be difficult to determine whether a change in an employee's behavior for addressing customer concerns actually resulted in reduced costs in terms of non-return of merchandise. In addition, HR practice flexibility may actually involve upfront implementation costs and encounter employee resistance initially, and therefore may not be cost effective in the short run. Interestingly, our results also show that high performance HR practices, such as selectivity in recruitment, training, variable compensation, and performance appraisal, have a greater effect on cost efficiency than the aggregate firm performance index $(b=$ -.24 versus $b=.15$ ). This indicates that, although they may require more upfront investment, these HR practices help achieve cost efficiency for the firm.

Our findings add to the research literature asserting that intangible assets residing in human coordination and skills can be sources of value and thus competitive advantage for the firm (Hitt, et al., 2001; Lei, et al., 1996; Miller \& Lee, 2001; Wright, et al., 2001). We suggest that HR flexibility dimensions enhance firm performance through at least two mechanisms. 
First, drawing on the notion of "requisite variety" (Weick, 1979), increased HR flexibility provides the firm a greater ability to respond to more substantial variation in the business environment. As Buckley (1968: 495) notes about the law of requisite variety, "Variety within a system must be at least as great as the environmental variety against which it is attempting to regulate itself. Put succinctly, only variety can regulate variety" (cited in Weick, 1979). Increased employee skill, behavior, and HR practice variety provide the firm with a more complex and varied set of routines that can be invoked to respond dynamically to changing and complex environments. While we do not directly assess the "fit" of flexibility with the competitive demands of the environment (Wright \& Snell, 1998), our findings suggest that variety provides the potential for greater fit by enhancing firm options to compete. Further study on the effects of environmental change on the relationship between HR flexibility and firm performance would supplement these findings.

Second, increased HR flexibility also implies a speedier response time to changing environmental conditions. Having varied employee skills as part of the HR capacity inventory, for example, suggests that the firm will be able to respond more rapidly than if the firm had to enter the open market and acquire skills to meet new demand conditions. Similarly, an increased facility in employee behavioral adaptability suggests that employees would be able to react more nimbly to change. Although we do not test long-term effects, our performance measures are at least partly collected after the flexibility measures. Further research should explore the degree to which the dimensions of HR flexibility are related to performance and cost efficiencies over longer periods of time.

Further research also should explore the relationship between high performance work practices and HR flexibility. In this study, we controlled for firms' use of practices such as selectivity in recruitment, extensive training, formal performance appraisal, and pay for 
performance. Our results show that, even when firms indicate that they engage in these practices, the components of flexibility had a significant independent effect on firm performance. However, our study also shows that the components of HR flexibility-particularly HR practice flexibility_are highly correlated with high performance work practices (ranging from $r=.28$ to .61). We understand these results as suggesting that the HR flexibility components may represent a process effect, that is, an indication of a firm's ability to react and adapt to changing conditions. High performance work practices, conversely, may represent a content effect; that is, the existence of particular types of practices that appear to be associated with higher firm performance. Our results suggest that both of these aspects, the ability to change (process) and specific practices (content), are essential to superior competitive advantage. Future research should investigate these effects simultaneously to assess in more detail how they are related, and indeed, whether one is possible without the other.

\section{Limitations}

Some limitations of this study deserve future investigation. The measures for skill, behavior, and HR practice flexibility could benefit from further refinement as well as replication in different industries. Although the moderate correlations between the dimensions are expected (Edwards, 2001; Law, Wong, \& Mobley 1998) and do not affect the results of our hypotheses tests, additional validation studies would be beneficial. A question that needs further investigation is whether the three lower-order dimensions used in this study comprise the total construct space of overall HR flexibility. The construct definition of HR flexibility we used was derived from the work of Milliman et al. (1991) and Wright and Snell (1998). Future researchers should attempt to identify other factors that might contribute to the level of overall HR flexibility of a firm. For example, the emerging work on alternative employment modes (Lepak, Takeuchi, 
\& Snell, 2003; Matusik \& Hill, 1998) may suggest other avenues that firms can pursue to achieve HR flexibility (see also Hitt et al., 1998).

Our study design does not allow us to rule out a reverse causal pattern suggesting that higher performing firms tend to invest more in HR flexibility. However, firms do not develop HR flexibility quickly; it is generated through a long term process of hiring and development of human resources, combined with strategic planning and coordination. While we cannot make conclusive statements about the direction of causality, we believe that the theoretical arguments positing a causal relationship between HR flexibility and firm performance hold merit. Generalizability is also a potential concern, since the study's sample is relatively small, and consists of only two industries. We selected these industries to ensure sufficient variation in business conditions. Given the strength and the unambiguous direction of this study's findings, it is likely that the results reported are robust. The concern about whether the current results can be generalized across all industries and economic sectors, however, remains valid and should be addressed in future studies.

A final study limitation was pointed out by one of the respondents who suggested that the nature of HR flexibility might vary according to the nature or category of jobs within a firm, especially in larger firms. This observation is consistent with the discussion of HR architecture, suggesting that different groups of employees have varying degrees of value and uniqueness (Lepak \& Snell, 2000). We have addressed this issue by instructing our respondents to focus only on the employees whose jobs are most central to the production and distribution of the firm's core products or services. Future researchers should address this limitation by designing studies that make a more fine-grained examination based on the firm's HR architecture.

\section{Managerial Implications}


This study's findings suggest to managers that investment in flexible skills and behaviors of employees are likely to pay off in terms of increased firm financial performance. This finding makes sense in an environment characterized by rapidly increasing available knowledge, increasing complexity, and increasing rapidity in the rate of change (Meyer, Goes, \& Brooks, 1995). Organizational change theorists argue that when environments change to a state incompatible with the nature of the organization, the organization has several strategic alternatives, including adapting to the changed environment, moving to a different environment, managing the environment into a more compatible state, or temporarily relying on slack resources, loose couplings, or other buffers (Huber \& Glick, 1995).

Another implication for managers is that their investment in human resources should not be focused on trying to forecast what employee skills they will need to accommodate future strategic, technological and marketing changes. Rather, they should focus on having sufficient variety in their skills and behaviors so that they have an increased chance of adapting to change that cannot be foreseen. This may mean, for example, increasing their attention to skill- and competency-based pay in addition to performance-based pay, hiring more highly educated employees rather than those that barely pass entrance requirements, and using selection methods that help to detect employee flexibility and adaptability, such as assessment centers and personality tests. It will also mean that flexible HR practices, such as teamwork structures, variable compensation plans, and adaptable performance appraisal are likely to warrant increased investment.

Our findings further suggest that if a firm is focused primarily on short term cost efficiency, its managers would be advised to invest primarily in skill flexibility, since the performance returns are likely to be more apparent. Overall, by helping to delineate what HR flexibility is comprised of, and showing a link between flexible skills, behaviors, and practices 
and firm performance, this study provides a rationale for managers to analyze and develop their HR flexibility with an eye to the bottom line. 


\section{REFERENCES}

Abowd, M. 1989. The effect of wage bargains on the stock market value of the firm. American Economic Review, 79: 774-800.

Addison, T., J., \& Hirsch, T. B. 1989. Union effects on productivity, profits, and growth: Has the long run arrived? Journal of Labor Economics, 7: 72-105.

Adler, P., Goldoftas, B., \& Levine, D. 1999. Flexibility versus efficiency? A case study of model changeovers in the Toyota production system. Organization Science, 10: 43-68.

Baker, W. E., \& Sinkula, J. M. 1999. The synergistic effect of market orientation and learning orientation on organizational performance. Academy of Marketing Science Journal, 27: 411-427.

Becker, B., \& Gerhart, B. 1996. The impact of human resource management on organizational performance: Progress and prospects. Academy of Management Journal, 39: 779-801.

Becker, B., \& Huselid, M. 1998. High performance work systems and firm performance: A synthesis of research and managerial implications. In G. Ferris (Ed.) Research in personnel and human resource management: 53-101. Stamford, CT: JAI Press.

Brockner, J., Grover, S., Reed, T., DeWitt, R., \& O’Malley, M. 1987. Survivors’ reactions to layoffs: We get by with a little help from our friends. Administrative Science Quarterly, 32: 526-542.

Buckley, W. 1968. Society as a complex adaptive system. In W. Buckley (Ed.), Modern systems research for the behavioral scientist: 490-513. Chicago: Aldine.

Cascio, W. F., Young, C. E., \& Morris, J. R. 1997. Financial consequences of employmentchange decisions in major U.S. corporations. Academy of Management Journal, 40: 1175-1189. 
Corbett, C., \& Van Wassenhove, L. 1993. Tradeoffs? What tradeoffs? Competence and competitiveness in manufacturing strategy. California Management Review, 35(4): 107120.

Datamonitor Industry Market Research. Annual 2000. The Gale Group, Inc.

Dean, J. W. Jr., \& Snell, S. A. 1996. The strategic use of integrated manufacturing: An empirical examination. Strategic Management Journal, 17: 459-481.

Delery, J. E., \& Doty, D. H. 1996. Modes of theorizing in strategic human resource management: Tests of universalistic, contingency, and configurational performance predictions. Academy of Management Journal, 39: 802-835.

De Meuse, K. P., Vanderheiden, P. A., \& Bergmann, T. J. 1994. Announced layoffs: Their effect on corporate financial performance. Human Resource Management, 33: 509-531.

Directory of Corporate Affiliations. 2000. Skokie, IL: National Register Publishing Company.

Edwards, J. R. 2001. Multidimensional constructs in organizational behavior research: An integrative analytical framework. Organizational Research Methods, 4: 144-192.

Eisenhardt, K. M., \& Martin, J. A. 2000. Dynamic capabilities: What are they? Strategic Management Journal, 21: 1105-1121.

Ellinger, A. D., Ellinger, A. E., Yang, B., \& Howton, S. W. 2002. The relationship between the learning organization concept and firms' financial performance: An empirical assessment. Human Resource Development Quarterly, 13: 15-21.

Garvin, D. A. 1993. Building a learning organization. Harvard Business Review, July-August: 78-91.

Garud, R., \& Kotha, S. 1994. Using the brain as a metaphor to model flexible production systems. Academy of Management Review, 19: 671-698. 
Gibson, C.B., \& Birkinshaw, J. 2004. The antecedents, consequences, and mediating role of organizational ambidexterity. Academy of Management Journal, 47: 209-226.

Greve, H. R. 1998. Managerial cognition and the mimetic adoption of market positions: What you see is what you do. Strategic Management Journal, 19: 967-988.

Hedberg, B. L. T. 1981. How organizations learn and unlearn. In P. C. Nystrom and W. H. Starbuck (Eds.), Handbook of organizational design. New York: Oxford University Press.

Hirsch, B. T. 1991. Labor Unions and the economic performance of firms. Kalamazoo, MI: W. E. Upjohn Institute.

Hitt, M. A., Bierman, L., Shimizu, K., \& Kochhar, R. 2001. Direct and moderating effects of human capital on strategy and performance in professional service firms: A resourcebased perspective. Academy of Management Journal, 44: 13-28.

Hitt, M. A., Keats, B. W., \& DeMarie, S. M. 1998. Navigating in the new competitive landscape: Building strategic flexibility and competitive advantage in the $21^{\text {st }}$ century. Academy of Management Executive, 12(4): 22-42.

Huber, G. P., \& Glick, W. H. 1995. Sources and forms of organizational change. In G. P. Huber and W. H. Glick (Eds.), Organizational change and redesign: 3-18. New York: Oxford University Press.

Hunt, S. D., \& Morgan, R. M. 1996. The resource advantage theory of competition: Dynamics, path dependencies, and evolutionary dimensions. Journal of Marketing, 60: 107-114.

Huselid, M. A. 1995. The impact of human resource management practices on turnover, productivity, and corporate financial performance. Academy of Management Journal, 38: 635-672. 
Kotter, J. P., \& Heskett, J. L. 1992. Corporate culture and performance. New York: The Free Press.

Larsson, R., \& Finkelstein, S. 1999. Integrating strategic, organizational, and human resource perspectives on mergers and acquisitions: A case survey of synergy realizations. Organization Science, 10: 1-26.

Law, K. S., Wong, C., \& Mobley, W. H. 1998. Towards a taxonomy of multidimensional constructs. Academy of Management Review, 23: 741-755.

Lei, D., Hitt, M. A., \& Bettis, R. 1996. Dynamic core competences through meta-learning and strategic context. Journal of Management, 22: 549-569.

Lengnick-Hall, C. A., \& Lengnick-Hall, M. L. 1988. Strategic human resource management: A review of the literature and a proposed typology. Academy of Management Review, 13: 454-470.

Lepak, D. P., \& Snell, S. 2000. The human resource architecture: Toward a theory of human capital allocation and development. Academy of Management Review, 24: 31-48.

Lepak, D.P., Takeuchi, R., \& Snell, 2003. Employment flexibility and firm performance: Examining the interaction effects of employment mode, environmental dynamism, and technological intensity. Journal of Management, 29: 681-704.

Lepine, J. A., Colquitt, J. A., \& Erez, A. 2000. Adaptability to changing task contexts: Effects of general cognitive ability, conscientiousness, and openness to experience. Personnel Psychology, 53: 563-594.

Lewis, M. W. 2000. Exploring paradox: Toward a more comprehensive guide. Academy of Management Review, 25: 760-776. 
MacDuffie, J. P. 1995. Human resource bundles and manufacturing performance: Organizational logic and flexible production systems in the world of auto industry. Industrial and Labor Relations Review, 48: 197-221.

March, J. G. 1991. Exploration and exploitation in organizational learning. Organization Science, 2: 7187.

Matusik, S. F., \& Hill, C. W. 1998. The utilization of contingent work, knowledge creation, and competitive advantage. Academy of Management Review, 23: 680-697.

Meyer, A. D., Goes, J. B., \& Brooks, G. R. 1995. Organizations reacting to hyperturbulence. In G. P. Huber \& W. H. Glick (Eds.), Organizational change and redesign: 66-111. New York: Oxford University Press.

Milkovich, G. T., \& Newman, J. M. 1999. Compensation. Boston: Irwin McGraw-Hill.

Miller, D., \& Lee, J. 2001. The people make the process: Commitment to employees, decision making, and performance. Journal of Management, 27: 163-189.

Milliman, J., Von Glinow, M. A., \& Nathan, M. 1991. Organizational life cycles and strategic international human resource management in multinational companies. Academy of Management Review, 16: 318-339.

Myers, R. H. 1990. Classical and modern regression with applications. $\left(2^{\text {nd }}\right.$ ed.). Boston: PWSKent.

Neter, J., Wasserman, W., \& Kutner, M. H. 1990. Applied linear statistical models. ( $3^{\text {rd }}$ ed.). Boston: Irwin.

Neuman, G. A., \& Wright, J. 1999. Team effectiveness: Beyond skills and cognitive ability. Journal of Applied Psychology, 84: 376-389.

Noe, R. A., Hollenbeck, J. R., Gerhart, B., \& Wright, P. M. 1994. Human resource management: Gaining a competitive advantage. Burr Ridge, IL: Irwin. 
Parthasarthy , R., \& Sethi, S. P. 1993. Relating strategy and structure to flexible automation: A test of fit and performance implications. Strategic Management Journal, 14: 529-549.

Paxson, M. C., Dillman, D. A., \& Tarnai, J. 1995. Improving response to business mail surveys. In Cox, B. G., Binder, D. A., Chinnappa, B. N., Christianson, A., Colledge, M. J., \& Knott, P. S. (Eds.), Business survey methods: 303-315. New York: John Wiley \& Sons.

Pulakos, E. D., Arad, S., Donovan, M. A., \& Plamondon, K. E. 2000. Adaptability in the workplace: Development of a taxonomy of adaptive performance. Journal of Applied Psychology, 85: 612-624.

Rangan, S. 1998. Do multinationals operate flexibly? Theory and evidence. Journal of International Business Studies, 29: 217-237.

Sanchez, R. 1995. Strategic flexibility in product competition. Strategic Management Journal, 16: $135-159$.

Shen, W., \& Cannella, A. A. 2002. Revisiting the performance consequences of CEO succession: The impacts of successor type, post succession senior executive turnover, and departing CEO tenure. Academy of Management Journal, 45: 717-733.

Teece, D. J., Pisano, G., \& Shuen, A. 1997. Dynamic capabilities and strategic management. Strategic Management Journal, 18: 509-533.

Thomke, S. 1998. Agile product development: Managing development flexibility in uncertain environments. California Management Review, 41(1): 8-30.

Thompson, J. D. 1967. Organizations in action. New York: McGraw Hill.

Weick, K. E. 1979. The social psychology of organizing. Reading, MA: Addison-Wesley.

Wright, P.M., \& Boswell, W.R. 2002. Desegregating HRM: A review and synthesis of micro and macro human resource management research. Journal of Management, 28: 247-276. 
Wright, P.M., Dunford, B.B., \& Snell, S. A. 2001. Human resources and the resource-based view of the firm. Journal of Management, 27: 701-721.

Wright, P. M., \& Snell, S. A. 1998. Toward a unifying framework for exploring fit and flexibility in strategic human resource management. Academy of Management Review, 23: 756-772.

Zollo, M. \& Winter, S. G. 2002. Deliberate learning and the evolution of dynamic capabilities. Organization Science, 13: 339-351. 
TABLE 1

Exploratory Factor Analysis for HR Flexibility Scales

$($ Skill flexibility $=$ SKF, Behavior flexibility $=$ BEF, HR Practice flexibility $=$ HRPF $)$

\begin{tabular}{|c|c|c|c|}
\hline Items & SKF & $\mathrm{BEF}$ & HRPF \\
\hline Our firm can shift employees to different jobs when needed & .80 & .08 & .12 \\
\hline Our employees can switch to new jobs in our company within a short time & .79 & .10 & .13 \\
\hline Our employees are capable of putting new skills to use within a short time & .76 & .26 & .01 \\
\hline Our firm is capable of meeting demand for new skills by retraining or shifting its existing employees & .76 & .17 & .04 \\
\hline We employ people with a broad variety of skills & .74 & .04 & .22 \\
\hline Many employees in our firm have multiple skills that are used in various jobs & .71 & .15 & .17 \\
\hline People in our firm can learn new skills within a short period & .70 & .01 & .07 \\
\hline The flexibility of our employees' work habits helps us to change according to market demands & .08 & .91 & .07 \\
\hline People in our firm change their work habits in response to changes in the competitive environment & .09 & .85 & .03 \\
\hline Our employees respond to changing situations within a short time & .07 & .85 & .25 \\
\hline People in our firm readily change their work habits as demanded by changes in the working environment & .10 & .84 & .14 \\
\hline Most of our employees are flexible enough to adjust to dynamic work requirements & .10 & .84 & .18 \\
\hline Our employees adjust to changing work requirements within a short period & .03 & .82 & .18 \\
\hline Our employees' response to the changing nature of their jobs helps us remain competitive in the market & .05 & .77 & .09 \\
\hline People in our firm change their behavior in response to customer requirements & .05 & .72 & .19 \\
\hline Flexibility of our HR practices helps us to adjust to the changing demands of the environment & .10 & .02 & .86 \\
\hline Our firm modifies its HR system to keep pace with the changing competitive environment & .07 & .06 & .85 \\
\hline Our HR practice parameters are designed so that they adjust quickly to changes in business conditions & .10 & .11 & .85 \\
\hline We make frequent changes in our HR practices to align the HR system with changing work requirements & .09 & .03 & .82 \\
\hline Changes in our HR practices enable us to remain competitive in the market & .02 & .05 & .77 \\
\hline Our HR practices adjust meaningfully to changed business scenarios & .06 & .07 & .76 \\
\hline Our HR practices, as a whole, are flexible & .13 & .08 & .75 \\
\hline Eigenvalues & 2.21 & 3.48 & 3.87 \\
\hline Total variance explained by each factor & $11 \%$ & $14 \%$ & $16 \%$ \\
\hline Cumulative variance explained by the factors & $11 \%$ & $25 \%$ & $41 \%$ \\
\hline
\end{tabular}


TABLE $2^{\mathrm{a}}$

Descriptive Statistics and Zero-Order Correlations

\begin{tabular}{|c|c|c|c|c|c|c|c|c|c|c|c|c|c|c|c|c|c|}
\hline & Variable & Mean & SD & 1 & 2 & 3 & 4 & 5 & $\overline{6}$ & 7 & 8 & 9 & 10 & 11 & 12 & 13 & 14 \\
\hline 1. & Industry & & & & & & & & & & & & & & & & \\
\hline 2. & Size & 7.12 & 1.80 & -.08 & & & & & & & & & & & & & \\
\hline 3. & Unionization (\%) & 34.99 & 27.24 & .00 & .26 & & & & & & & & & & & & \\
\hline 4. & Debt-equity & 51.24 & 64.13 & -.32 & .31 & -.07 & & & & & & & & & & & \\
\hline 5. & Capital intensity & 32.61 & 17.35 & -.35 & .04 & .04 & .38 & & & & & & & & & & \\
\hline 6. & R\&D intensity & 0.06 & 0.07 & .09 & -.13 & -.06 & -.40 & -.25 & & & & & & & & & \\
\hline 7. & Skill flexibility & 4.84 & 0.81 & -.11 & .01 & -.19 & -.15 & .22 & .32 & .89 & & & & & & & \\
\hline 8. & Behavior flexibility & 4.71 & 0.90 & -.12 & .00 & -.02 & -.09 & .20 & .38 & .59 & .92 & & & & & & \\
\hline 9. & HR practice flexibility & 4.67 & 0.79 & -.13 & -.06 & -.14 & -.08 & -.02 & .41 & .35 & .50 & .90 & & & & & \\
\hline 10. & High performance HR practices & 18.56 & 2.87 & .08 & .03 & -.27 & .04 & .18 & .29 & .28 & .41 & .61 & & & & & \\
\hline 11. & Firm performance index & 24.47 & 12.98 & .07 & .09 & .23 & .23 & .17 & .25 & .28 & .18 & .31 & .33 & & & & \\
\hline 12. & Return on sales & 5.71 & 4.95 & .28 & -.28 & -.02 & -.47 & -.06 & .23 & .37 & .04 & .19 & .31 & .10 & & & \\
\hline 13. & Operating profit per employee ${ }^{b}$ & 2.22 & 1.57 & -.04 & -.11 & .21 & .03 & .21 & .27 & .41 & .28 & .37 & .38 & .81 & .40 & & \\
\hline 14. & Sales per employee ${ }^{b}$ & 16.54 & 6.46 & -.08 & -.07 & .33 & .27 & .15 & .24 & .28 & .23 & .34 & .30 & .79 & .02 & .71 & \\
\hline 15. & Cost of sales over sales & 69.42 & 13.64 & .07 & .10 & .09 & .08 & -.03 & -.32 & -.26 & -.17 & -.13 & -.36 & -.33 & -.32 & -.65 & -.25 \\
\hline
\end{tabular}

${ }^{a}$ Numbers on the diagonal are Cronbach's alpha, where appropriate; correlations greater than .17 are significant at the .05 level.

b ,000 dollars per employee. 
TABLE 3

Skill, Behavior, HR Practice Flexibility and Firm Financial Performance

\begin{tabular}{lcc}
\hline Hierarchical Effects & $\begin{array}{l}\text { Firm } \\
\text { Financial } \\
\text { Performance }\end{array}$ & $\begin{array}{l}\text { Cost of Sales } \\
\text { over Sales }\end{array}$ \\
\hline Step 1: Controls & .04 & .07 \\
Industry & -.07 & .07 \\
Size & $.22^{* *}$ & .07 \\
Unionization & $-.35^{* * *}$ & .05 \\
Debt-equity & .12 & -.07 \\
Capital intensity & $.37^{* * *}$ & $-.17^{*}$ \\
R\&D intensity & $.15^{*}$ & $-.24^{* *}$ \\
High performance HR practices & & \\
Step 2: Independent variables & $.30^{* * *}$ & $-.18^{*}$ \\
Skill Flexibility (H1, H4a) & $.21^{* *}$ & -.03 \\
Behavior Flexibility (H2, H4b) & $.23^{* *}$ & -.04 \\
HR Practice Flexibility (H3, H4c) & .08 & .04 \\
$\quad$ Change in R & .28 & .06 \\
$\quad$ Adjusted R & $6.02^{2 * *}$ & $2.81^{*}$ \\
\hline
\end{tabular}

Standardized regression coefficients are reported

$* \quad \mathrm{p}<.05$

$* * \mathrm{p}<.01$

$* * * \mathrm{p}<.001$ 


\section{APPENDIX \\ High Performance HR Practices Index}

\section{Components}

(Likert-type 7-point scales, 1 = strongly disagree, 7 = strongly agree).

1. Selectivity in recruitment (Cronbach's alpha $=.71)$

a. We screen many applicants to fill job openings.

b. We use many different recruiting sources.

2. Training (Cronbach's alpha $=.93)$

a. We spend more money per employee on training than our competitors

b. We offer many different types of training programs

c. Our employees spend more hours a year in training than our competitors

3. Variable compensation (Cronbach's alpha $=.63$ )

a. A large portion of our employees' compensation is contingent upon performance

b. The amount earned by our employees is determined primarily by an incentive plan rather than by a guaranteed-income plan

4. Performance appraisal (Cronbach's alpha $=.86$ )

a. Our performance appraisal system uses multiple levels of evaluation criteria (individual-, group-, firm-level)

b. Our performance appraisal system uses multiple inputs (peers, customers, subordinates etc.) 


\section{BIOGRAPHICAL STATEMENTS}

Mousumi Bhattacharya is assistant professor of management in the Charles F. Dolan School of Business at Fairfield University. She received her Ph.D. in strategy and human resource management from Syracuse University. Her research interests include flexibility of organizations, integration of human resource management (HRM) with strategy, and application of real options theory in HRM.

Donald E. Gibson is associate professor of management in the Charles F. Dolan School of Business at Fairfield University. He received his Ph.D. in management from the Anderson School of Management at UCLA. His research interests include the attributes and impact of organizational role models, the management of individual emotional experience and expression in organizations, anger in the workplace, and effective organizational communication.

D. Harold Doty currently serves as Professor and Dean of the College of Business and Economic Development at The University of Southern Mississippi. He received his Ph.D. in management from the University of Texas at Austin. Prior to joining Southern Mississippi he served on the faculty at the University of Arkansas, Fayetteville and Syracuse University. His research interests include organizational effectiveness, organization design, configurational theory, and strategic human resource management. His previous research has been awarded the Academy of Management Journal Best Article Award and the Scholarly Achievement Award by the Human Resource division of the Academy of Management. 